\title{
EMBRYONIC MORTALITY AND BROILER CHICK QUALITY (Gallus gallus) FROM GLASS-SHELLED EGGS
}

\section{MORTALIDADE EMBRIONÁRIA E QUALIDADE DO PINTO AO NASCER ORIUNDO DE OVO DE CASCA VÍTREA DE MATRIZ PESADA (Gallus gallus)}

\author{
Maria Julia Macedo Franco ${ }^{1}$ ORCID - http://orcid.org/0000-0003-4151-3809 \\ Otávio Cintra Lemos Olivieri ${ }^{1 *}$ ORCID - http://orcid.org/0000-0003-2781-906X \\ Evandro De Abreu Fernandes ${ }^{1}$ ORCID - http://orcid.org/0000-0002-5806-3763 \\ Paulo Lourenço da Silva1 ORCID - http://orcid.org/0000-0001-8186-8693 \\ Raphael Ribeiro Fonseca ${ }^{1}$ ORCID - http://orcid.org/0000-0001-5416-827X \\ Belchiolina Beatriz Fonseca1 ORCID - http://orcid.org/0000-0001-8485-078X
}

1Faculdade de Medicina Veterinária, Universidade Federal de Uberlândia, Uberlândia, MG, Brazil.

*Corresponding author - otavio.ufu@hotmail.com

\begin{abstract}
The glass-shelled egg has various points on the surface with light gray coloration, which becomes more visible with the passage of egg storage period. The objective of this work was to evaluate the stage of embryonic mortality, egg weight during the incubation period, hatch window, and quality of chicks at hatch from glass-shelled egg. The research was divided into two parts. In the first part, 80 eggs from 45 weeks old hens were incubated, being half normal eggs and half glass-shelled eggs, while in the second part, 80 eggs from 70 weeks old hens from the same flock as the previous one were incubated. Again, half were normal shelled and half were glass-shelled eggs. No differences were observed for embryonic mortality, egg weight, hatch quality (hatch weight, uniformity, and navel quality), and hatch window between normal and glass-shelled eggs from hens of 45 and 70 weeks of age. However, there was higher contamination in glass-shelled egg from 70 -week-old breeder hens. The results show that the presence of glass-shelled egg does not seem to interfere with the quality of the chick at hatch in the breed, ages, and studied conditions, but causes higher contamination in glassshelled egg from 70-week-old breeder hens.
\end{abstract}

Keywords: Hatch Window. Chick quality. Embryonic development.

\section{Resumo}

Ovos de casca vítrea apresentam em suas superfícies pontos com coloração cinza claro de vários diâmetros, que ficam mais visíveis com o decorrer do período de armazenagem. Objetivou-se no trabalho, avaliar a fase de mortalidade embrionária, peso do ovo durante o período de incubação, intervalo de tempo de nascimento e a qualidade dos pintos ao nascerem oriundos de ovos de casca vítrea. A pesquisa foi dividida em duas partes. Na primeira parte, ocorreu a incubação de 80 ovos provenientes de matrizes com 45 semanas de idade sendo metade ovos normais e metade ovos vítreos e na segunda parte, foram incubados 80 ovos provenientes de matrizes com 70 semanas de idade do mesmo lote do anterior. Desses, metade eram normais e metade eram vítreos. Não houve diferença para mortalidade embrionária, peso do ovo, qualidade dos pintos ao nascerem (peso do pinto ao nascer, qualidade do umbigo e uniformidade) e intervalo de tempo de nascimento entre os ovos vítreos e normais oriundos de matrizes de 45 e 70 semanas de idade. Porém ovos de casca vítrea oriundos de matrizes de 70 semanas de idade apresentaram maior índice de contaminação. 
Palavras chave: Intervalo de tempo de nascimento. Qualidade do pinto. Desenvolvimento embrionário.

Received on October 2nd, 2017.

Accepted on April 15th, 2019.

\section{Introduction}

Brazil stands out in the ranking of production and export of chicken meat. According to the United States Department of Agriculture ${ }^{(1)}$, Brazil overtook China in 2015 and became the world's secondlargest chicken producer. Hence, hatcheries must achieve good hatching results with excellent chick quality, so broiler producers can count on flocks that will guarantee the market demand.

For the embryo to develop and keep the internal components of the egg, eggshell quality is extremely important. According to Vilela ${ }^{(2)}$, the main functions of the shell are to be a physical barrier against the entry of pathogens and protection of components inside the egg; prevention of large losses of moisture, which would result in egg dehydration; assist in gas exchanges, which occur through the pores present in the shell; and relevant source of calcium during embryo development.

Egg quality helps in the hatch of healthy chicks. Healthy chicks have a well-healed navel, clean and dry, without membrane and/or yolk exposure, without defects in the eyes, skin lesions, and leg injuries. Furthermore, healthy chicks are responsive to the environment.

The artificial incubation process is fundamental to modern poultry farming and favors performance and yield. In this way, both the egg-producing farm and the hatchery are directly related to obtaining quality chicks. Glass-shelled eggs are a type of mottled eggs, identified by having mottling on its surface with light gray coloration of various diameters, which become more visible during the period of egg storage ${ }^{(2)}$. This kind of eggs emits a tinkling sound when flicked with a fingernail, resembling the sound when a glass is flicked ${ }^{(3)}$.

The age of hens may influence the appearance of these patches on the surface of the shell because the structure of the papillary layer of the shell becomes coarser, resulting in different moisture inside the shell. This fact allows increases and growths in the sizes of spots on the shell. Other possible causes may be dietary manganese deficiency and differences between chicken lines ${ }^{(3)}$.

There are no papers in the literature relating glass-shelled eggs with worsening of egg incubation, but if this change occurs, this investigation is important. Therefore, the objective of this study was to evaluate the effects of eggs with glass-shelled on embryonic mortality, hatch window, level of contamination, and chick quality at hatch.

\section{Material and methods}

The experiment was conducted at the Laboratory of Poultry Incubation of the Universidade Federal de Uberlândia. The methodology used was approved by the Comitê de Ética de Uso Animal (CEUA) under the Protocol No. 029/16. The eggs used came from a farm of heavy breeders located in the city of Uberlândia, Minas Gerais. Broiler breeder hens consisted of AP95 breed (Aviagen) grown in the Dark House system during the rearing period (1 to 21 weeks of age) and open in the production period 
(21 to 70 weeks of age). Egg collection was manual, using eggs from the first collection of the day. Eggs were fumigated with $2.40 \mathrm{~g} / \mathrm{m}^{3}$ of paraformaldehyde on leaving the farm.

A total of 160 eggs were used and divided into two groups. In the first group, 80 eggs from breeder hens with 45 weeks of age were incubated and in the second group, 80 eggs from breeder hens with 70 weeks of age from the same flock as the previous one was incubated.

The experiment was carried out in a completely randomized design. The number of eggs sampled was 40 eggs per shell type at each age. The glass-shelled egg can be visualized in the supplementary material.

In the laboratory, eggs from the same house and collected at the same time were stored for 48 hours at room temperature and, immediately before being incubated, they were separated according to their macroscopic characteristics in two categories: eggs with a glass-shelled (V) and eggs of normal shell $(\mathrm{N})$. After separation, the eggs were weighed in a high precision scale (AND HR-200). All eggs were identified and placed in an incubator in an intercalated fashion between an egg glassy shell and a normal egg. Only on the 21 st day of incubation, before hatching, the eggs were physically separated by categories to avoid mixing the chicks. It is worth mentioning that the incubator used (Chocmaster $\left.{ }^{\circledR}\right)$ is very small (100 eggs) when compared to an industrial one (3000-5000 eggs) so that the internal environment does not change considerably.

The eggs were incubated for 21 days, from 1 to 18 days at $37.50{ }^{\circ} \mathrm{C}$, humidity at $65 \%$, ventilation and turning every 2 hours. From the 18th day of incubation, the turning process was off, the variables temperature, ventilation, and humidity were not changed, and a physical barrier was placed inside the incubator so that the chicks of each category did not mix. This barrier allowed the circulation of air uniformly to both sides. During the incubation period, the eggs were removed from the incubator and weighed again with an eight-day interval between measurements.

After hatch, the following parameters were evaluated: embryonic mortality; hatch window; chick quality at hatch. After the removal of newly hatched chicks from the incubator, every four hours, embryo diagnosis was performed on non-hatched eggs.

In order to classify the embryonic mortality, the intervals reported by Ulmer-Franco ${ }^{(4)}$ were considered: early, intermediate, and late embryonic mortality eggs that ceased embryonic development between $0-7,8-14$, and 15-21 days, respectively.

Hatch window of chicks was evaluated by counting the time in hours from the first to the last hatched chick. The aspects evaluated in quality chicks were: red hocks, active and alert behavior, deformities, and navel characteristics at hatch. Navel quality was evaluated through the following scores: umbilicus with navel cord, navel healed with residue, normal umbilicus, open and unhealed navel, and black or bruised navel. For weight analyses, the Kolmogorov-Smirnov test was used to evaluate if the data were parametric, and later the normality of the Student's t-test at 5\% of significance was confirmed. For embryonic mortality, the chi-square test was performed followed by Fisher's test. For uniformity of chicks and navel quality, the binomial of proportions test was performed. The seconddegree regression model was used to evaluate the curves of the hatch window. The Biostat program was used to compare hatch window curves and the GraphPad Prism program for other evaluations.

\section{Results and Discussion}

No differences were observed in embryo mortality (early, intermediate, and late) of eggs from 
breeders of 45 and 70 weeks (Tables 1 and 2). There was also no difference in the index of visually contaminated eggs from breeders of 45 weeks (Table 1). All contaminated eggs from 45 -week-old breeder hens were identified during embryo diagnosis due to the characteristic staining and scent of contamination, but these eggs did not burst inside the incubator. The index of contaminated eggs was higher in glass-shelled eggs at the age of 70 weeks $(p=0.0201)$, and all were bangers (Table 1$)$.

Table 1. Phase of embryonic mortality and contamination of normal and glass-shelled eggs from breeder hens with 45 weeks of age

\begin{tabular}{lcccc}
\hline Mortality & $\begin{array}{l}\text { Mortality (\%) } \\
\text { weeks of age }\end{array}$ & P value & $\begin{array}{l}\text { Mortality(\%) } \\
\text { weeks of age }\end{array}$ & P-value \\
\hline Early normal & 12.5 & 1.00 & 12.5 & 0.71 \\
Early glass-shelled & 15 & & 15 & \\
$\begin{array}{l}\text { Intermediate normal } \\
\text { Intermediate glass- }\end{array}$ & 15 & 0.72 & 7.5 & 1.00 \\
shelled & 7.5 & 1.00 & 15 & 0.48 \\
Late normal & 5 & & 7.5 & \\
Late glass-shelled & 10 & 0.28 & 0 & \\
$\begin{array}{l}\text { Contaminated normal } \\
\text { Contaminated }\end{array}$ & 2.5 & & $10^{*}$ & 0.02 \\
glass-shelled & 5.0 & & & \\
\hline
\end{tabular}

" Bangers"

There are few studies on glass-shelled eggs in the literature. However, the study by Vilela ${ }^{(2)}$ with egglaying hens showed statistical differences in the concentration of calcium, mineral matter, specific gravity, and number of pores in eggshells. According to this study, glass-shelled egg had lower values for calcium, mineral matter, specific gravity, and pores when compared to normal eggs. During embryonic development, the shell is an important source of calcium for the embryo ${ }^{(5,6)}$. Shell with less calcium may result in poor skeletal development and low hatch rate ${ }^{(7)}$.

Due to the lower amount of mineral matter, Vilela ${ }^{(2)}$ concluded that glass-shelled eggs are more fragile than normal. Another finding from Vilela ${ }^{(2)}$ when comparing normal to glass-shelled eggs for shell thickness was that after 50 weeks of age, the eggs had thinner shells than normal eggs, indicating that glass-shelled eggs are weaker than normal. The presence of adequate thickness and resistance in the eggshell preserve it from contaminations ${ }^{(8)}$, which also results in a better hatching rate. Specific gravity is a physical measure that determines shell density, which is related to shell thickness ${ }^{(9)}$. Therefore, the fact that glass-shelled eggs have a lower specific gravity makes it possible to conclude that the quality of eggshells is inferior to that of normal eggs ${ }^{(2)}$. Shell quality is a factor that interferes with early embryonic mortality. Coleman and $\mathrm{McDaniel}^{(10)}$ found that eggs with lower specific gravity had a higher number of early embryo mortality, differing from the results obtained in the experiment conducted by Roque and Soares ${ }^{(11)}$, in which eggs with higher specific gravity had lower embryonic mortality in the intermediate and late phases. Pores in eggshells are formed when columns of adjacent calcium crystals do not come together during the mineralization of the shell on the isthmus. These pores are essential for gas exchange between the environment and inner $\operatorname{egg}^{(8)}$. As stated by Silva ${ }^{(12)}$, porosity and thickness are the features most related to embryonic development. The shell containing few numbers of pores are more resistant to the entry of bacteria into the $\operatorname{egg}^{(13)}$.

According to Vilela ${ }^{(2)}$, although glass-shelled egg had fewer pores, they were larger than the pores of normal eggs, and it would lead to microorganisms coming in and higher loss of water and $\mathrm{CO}_{2}$. 
Based on the findings of Vilela ${ }^{(2)}$ in commercial laying hens described above, higher embryonic mortality in glass-shelled eggs would be expected due to the inferior quality of the shell when compared to the normal eggs, but the results of this work did not prove this finding. This unexpected result can be explained by two hypotheses: (i) Vilela ${ }^{(2)}$ worked with light laying eggs of a breed totally different from the breeder hens so it is not known if in eggs of breeder hens the result of shell quality would be similar to eggs of laying hens; (ii) for a good hatching of the chicks, shell quality may not be so good as to be a resistance to the chick exit, but neither so bad as to lead to damage to the shell or compromise the formation of the chick skeleton. Smaller amounts of calcium in the eggshell may lead to poor skeletal system development ${ }^{(4)}$. In this sense, it is possible that even with a lower shell quality, it does not cause changes in embryonic mortality. Thus, it is important to conduct other studies on both the quality of the eggshell and on the birth of chicks from eggs of heavy eggs.

It is important to clarify that in this study, embryonic mortality in both groups was very high when compared to the embryonic mortality data from an industry, especially early embryonic mortality. It is necessary to emphasize that the incubation process during this experiment, as well as the incubator, widely differs from the industrial process. In this work, eggs from 45-week-old breeder hens were disinfected only when they left the farm, while eggs from 70-week-old breeder hens had palliative disinfection only to avoid more bangers. In addition, the turning process took place every 2 hours and moisture control is not possible, as is the case of industrial hatcheries.

Although there were no bangers in eggs from 45-week-old breeder hens, these eggs were present in glass-shelled eggs from 70 -week-old breeder hens $(\mathrm{p}=0.0201)$ (Table 1$)$. At 11 days of incubation, the first 70-week glass-shelled egg of breeder hens burst into the incubation machine. Thus, there was no interference in the subsequent results because the incubator was sanitized, disinfected, and $0.5 \mathrm{ml} /$ $\mathrm{m}^{3}$ formalin was placed for 4 hours. After 15 days of incubation, the other eggs exploded, and the same procedure was performed. It is worth noting that such eggs were far from the first one that burst inside the machine. However it is not possible to affirm that the contamination index increased in glass-shelled eggs from old breeder hens since there is the possibility of cross-contamination. Higher contamination would be justified in glass-shelled eggs since, as a cause of poor shell quality, there is a higher possibility of egg contamination. However, future studies should be performed due to the possibility of cross-contamination.

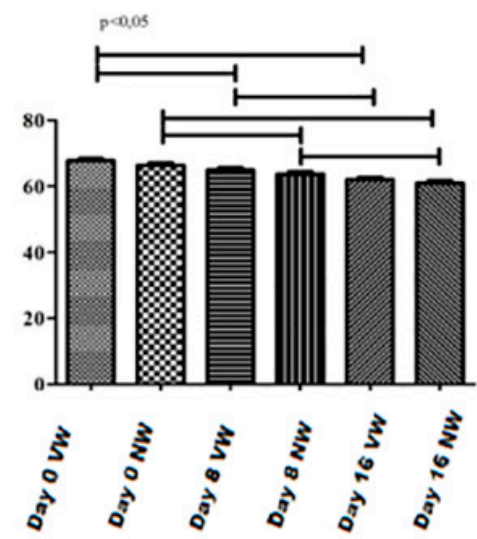

A

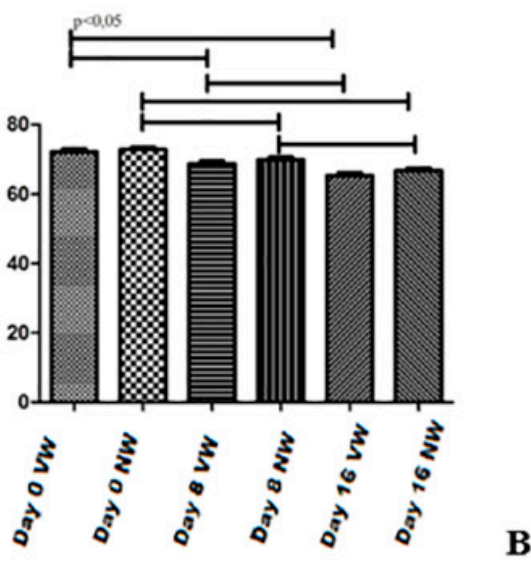

Figure 1. Chart with normal (NW) and glass-shelled egg (VW) weight from 45-week old breeder hens (A) and 70-week old breeder hens (B).

Legend - There was a difference between the different days of weighing in the same treatment, but these results were not shown in the graph because it is an expected result. 
The zero-day was the day the eggs were incubated. Comparing eggs from different treatments at the same age, there was no difference between the weight of glass-shelled eggs and normal eggs (Figure 1).

According to Vilela ${ }^{(2)}$, glass-shelled eggs have lower specific gravity than normal eggs. According to the study by Roque and Soares ${ }^{(11)}$, eggs with lower specific gravity had a higher percentage of weight loss during the first 18 days of incubation than eggs with higher specific gravity. When correlating the findings of Vilela ${ }^{(2)}$ and Roque e Soares ${ }^{(11)}$, a statistical difference would be expected between weights of normal and glass-shelled eggs at different ages during the experiment.

Still considering the absence of difference between weights of normal and glass-shelled eggs (Figure 1) and taking into account the results found by Vilela ${ }^{(2)}$ related to the pore size of glass-shelled eggs being larger than those of normal eggs, which could lead to a higher loss of water by glass-shelled eggs, glass-shelled eggs would be expected to lose more water than normal eggs during incubation.

The results found for weight loss during the incubation process were expected since according to French $^{(14)}$, eggs should lose 11 to $12 \%$ of their initial weight from the moment they are placed in the setter until the transfer (18 Days). Another study that matches with our results was Vilela ${ }^{(2)}$, who found that after 24 hours of storage, the weight of glass-shelled eggs did not present statistical differences when compared to the weight of normal eggs, with values ranging from 62.75to 62.88g.

The results found for hatch weight of the chicks are shown in Figures 2A and 2B. For both chicks from 45- and 70-week-old breeder hens, the weights of normal chicks did not present statistical difference when compared to glass-shelled chicks.

A

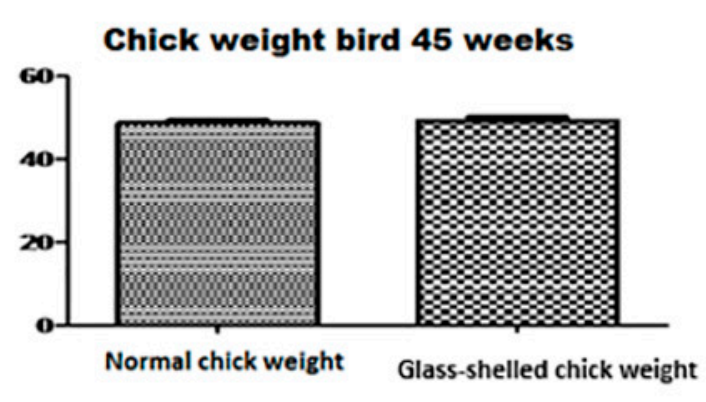

B

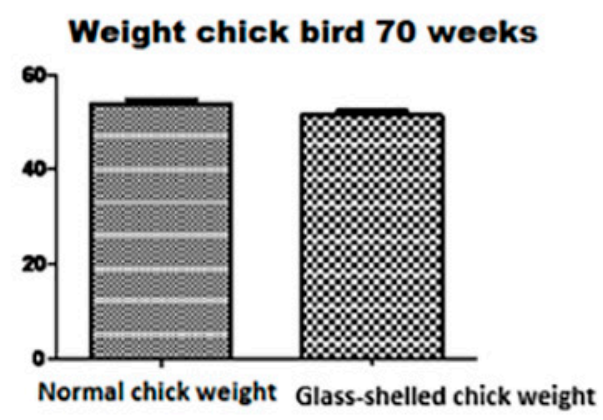

Figure 2. Graph with weight, in grams, of normal and glass-shelled chicks coming from breeder hens at 45 weeks of age (A) and 70 weeks of age (B).

Even with the results found by Vilela ${ }^{(3)}$, glass-shelled eggs have pores with larger diameters and lower specific density when compared to normal eggs, which indicates lower quality, these facts do not seem to have influenced in greater loss of water and consequent dehydration of glass-shelled embryos. It is because 1-day-old chicks both glass-shelled and normal at both ages did not present statistical differences for weight.

The findings related to nail quality of normal and glass-shelled 1-day chicks from 45- and 70-week old breeder hens are shown in Table 2. 
Table 2. Navel quality of normal and glass-shelled chicks from 45 - and 70 -week old breeder hens

\begin{tabular}{|c|c|c|c|c|}
\hline & $\begin{array}{c}\text { Normal } \\
45 \\
\text { Weeks } \\
(\%) \\
\end{array}$ & $\begin{array}{c}\text { Glass-shelled } \\
45 \text { weeks } \\
(\%) \\
\end{array}$ & $\begin{array}{c}\text { Normal } \\
70 \\
\text { weeks } \\
(\%) \\
\end{array}$ & $\begin{array}{c}\text { Glass-shelled } \\
70 \text { weeks } \\
(\%)\end{array}$ \\
\hline Navel with drawstring & 5 & 10 & 5 & 7.5 \\
\hline Navel with residue & 35 & 30 & 25 & 12.5 \\
\hline Normal navel & 15 & 12.5 & 0 & 5 \\
\hline Black or poorly healed navel & 10 & 12.5 & 12.5 & 15 \\
\hline Yolk out of the cavity & 0 & 2.5 & 0 & 0 \\
\hline
\end{tabular}

According to Deeming ${ }^{(15)}$, the incorrect absorption of embryonic tissues and yolk sac until the time when the navel closes and high temperature at hatch may cause the black navel. The poorly healed navel may occur due to the high humidity during the period when the yolk is being absorbed, preventing the contraction of membranes, and when the temperature is quite high between the 11th and 18th day of incubation ${ }^{(15)}$.

The amount of residual yolk that the chick has at hatch influences the healing of the umbilicus because the higher the amount of yolk, the greater the chances of complications in the navel healing and entrance of microorganisms. Navel with the absence of residues, healed and closed is considered of better quality because the presence of these characteristics decreases the chances of infection ${ }^{(4)}$.

In this work, there was a high index of chicks with residues in the navel and black navel or poorly healed. The index of chicks with residues exceeded the index of normal chicks. It can affect chick development because according to Fasenko and $\mathrm{O}^{\prime} \mathrm{Dea}^{(16)}$, chicks that have navels with inferior conditions do not present effective growth when compared to those with normal navels.

No statistical differences were observed between normal and glass-shelled chicks at both ages for uniformity (Table 3).

Table 3. Uniformity of chicks from 45 - and 70 -week old breeder hens

\begin{tabular}{lccc}
\hline & Normal & Glass-shelled & P \\
\hline 45 weeks & 87.5 & 74.07 & 0.294 \\
70 weeks & 88.24 & 92.3 & 1.000 \\
\hline
\end{tabular}

High amounts of $\mathrm{CO}_{2}$ and moisture, with decreased oxygen content, may delay embryo growth and, at the time of hatch, decrease their uniformity ${ }^{(17)}$.

There is a conception in poultry that broilers need to hatch from eggs with similar weight to have a correct weight uniformity ${ }^{(18)}$. Egg weight has a high correlation with chick weight at hatch ${ }^{(19)}$. Thus, we can conclude that a low egg weight uniformity can generate a wider spread on the chick weight at hatch. However, no difference was observed between the uniformity of chicks from glass-shelled and normal eggs.

No difference was observed between the hatch window of embryos originating from glass-shelled and normal eggs (Figures 3a, 3b, 3c and 3d). 

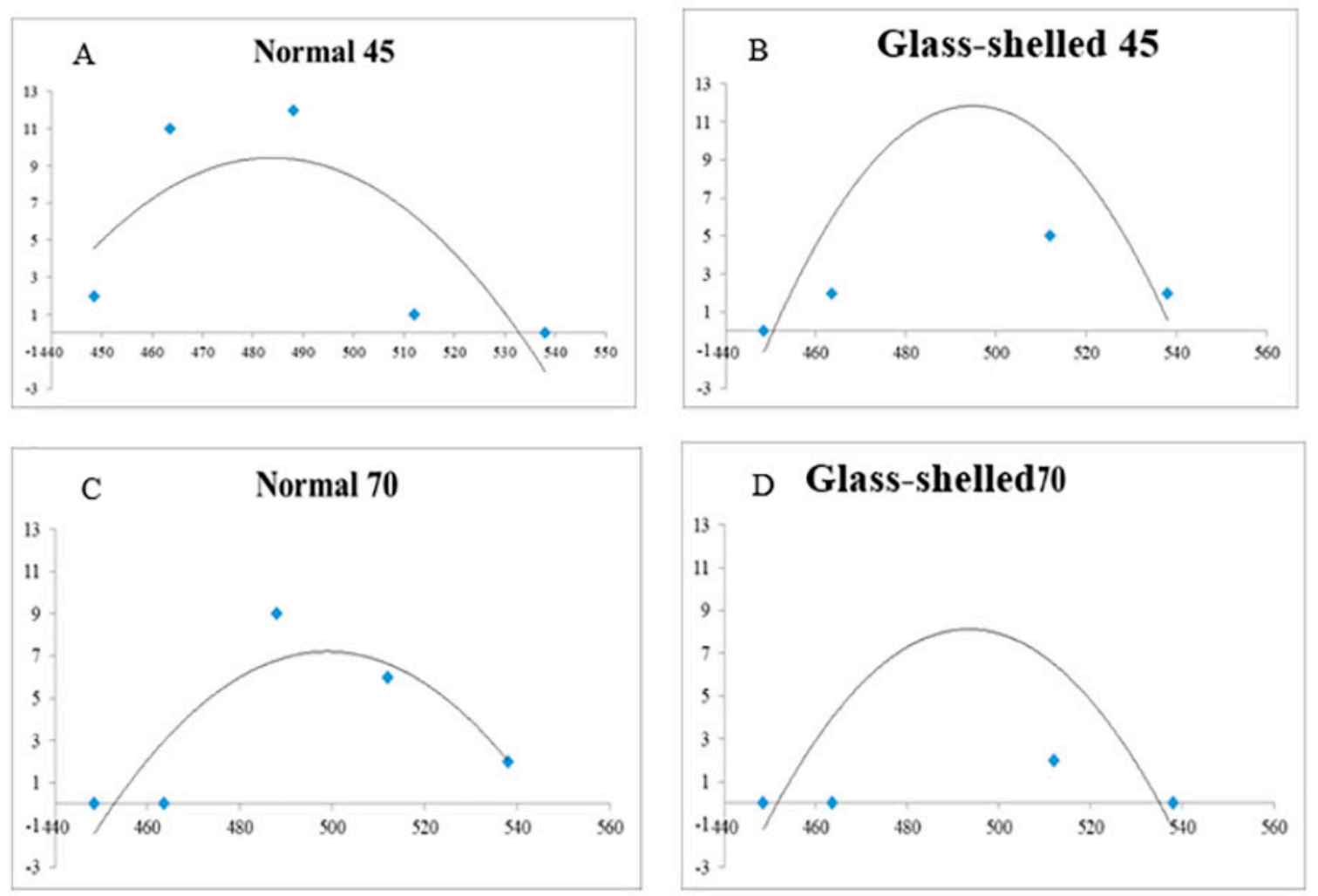

Figures 3a, 3b, 3c, and 3d represent the curves of the hatch window from normal and glass-shelled chicks from mating of 45 and 70 weeks of age.

Legend - The abscissa axis shows the incubation period, in hours, while the axis of the ordinates shows the percentage of hatched chicks.

According to Hodgetts ${ }^{(20)}$, not always all chicks will be hatched on the 21 st day of incubation. Even in hatcheries considered to be the best, there may be a 24-hour interval between the first and the last chick. Some hatcheries show a hatch window much longer than 24 hours, generating considerable loss of water in the first hatched chicks and poor umbilical cicatrization of chicks hatched last.

The hatch window considered ideal is the one that presents in the graph a normal distribution, with the presence of a narrow base and an elevated peak. The fact that the base is narrow indicates a shorter time span between the chick that is hatched first and that hatched last. Moreover, the high peak indicates more agglomeration of the hatching and symmetry.

Glass-shelled egg, when compared to normal eggs, have larger pores and less specific gravity. The presence of larger pores in glass-shelled eggs could favor a greater loss of water by the egg ${ }^{(2)}$. According to Roque and Soares ${ }^{(11)}$, a greater weight loss during the first 18 days of incubation can occur in eggs with lower specific gravity. Differences between shell qualities could also result in a different hatch window. The hypotheses for the no occurrence of this event have already been discussed previously.

Although the results are consistent, other studies should be performed to verify other variables, for example, if there is a difference between levels of glass-shelled surfaces between one egg and another or if in other breeds, the results of this study will be repeated. There is also a need to carry out further studies on contamination, especially on eggs from old chickens. 


\section{Conclusions}

The results of this work show no interference in the embryonic viability or quality of chicks from glass-shelled eggs of heavy breeder hens at 45 and 70 weeks of ages in the studied breed. However, there is increased contamination of glass-shelled eggs from 70 -week old hens.

\section{References}

1. USDA - UNITED STATES DEPARTMENT OF AGRICULTURE, 2017 [cited 2017 aug 11] Avaible from: https://www.usda.gov

2. Vilela DR, Carvalho LSS, Fagundes NS, Fernandes EA. Qualidade interna e externa de ovos de poedeiras comerciais com casca normal e vítrea. Cienc Anim Bras [Internet]. 2016 oct/dec [cited 2017 aug 11]; 17 (4): 509- 518. Available from: http://revistas.bvs-vet.org.br/cab/article/view/34333/38401

3. Kashimori A, The Illustrated egg handbook. 1 ed. Leicestershire: Context; 2017. 157p. Avaible from: https:// www.theillustratedegg.com/

4. Ulmer-Franco AM, Frasenko GM, O'dea Christopher EE. Hatching egg characteristics, chick quality, and broiler performance at 2 breeder flock ages and from 3 egg weights. Poultry Science; 2010 89(12): 2735-2742. Available from: https://academic.oup.com/ps/article/89/12/2735/1493303

5. Lavelin, I, Meire N, Pines M. New Insight in eggshell formation. Poultry. Science. 2000; 79: 1014-1017. Available from: https://academic.oup.com/ps/article/79/7/1014/1659699

6. Moran Jr. ET. Nutrition of the developing embryo and hatchling. Poultry Science. 2007; 86: 1043-1049. Available from: https://academic.oup.com/ps/article/86/5/1043/1620717

7. Tuan RS, Lynch MH. Effect of experimentally induced calcium deficiency on the developmental expression of collagen types in chick embryonic skeleton. Developmental Biology. 1983; 100(2): 374-386. Available from: https://www.sciencedirect.com/science/article/pii/0012160683902324

8. Carvalho LSS, Fernandes EA. Formação e qualidade da casca de ovos de reprodutoras e poedeiras comerciais. Journal of Veterinary Medicine. 2013; 7(4): 35-44. Available from: http://journals.ufrpe.br/index. php/medicinaveterinaria/article/view/604

9. Rosa, PS, Avila, VD. Variáveis relacionadas ao rendimento da incubação de ovos em matrizes de frangos de corte. Concórdia: Embrapa Suínos e Aves. 2000. Available from: http://docsagencia.cnptia.embrapa.br/suino/ comtec/cot246.pdf

10. Coleman MA, McDaniel GR. The Effect of Light and Specific Gravity on Embryo Weight and Embryonic Mortality. Poultry Science. 1975; 54(5): 1415-142. Available from: https://academic.oup.com/ps/articleabstract/54/5/1415/1558572

11. Roque L, Soares MC. Effects of Eggshell Quality and Broiler Breeder Age on Hatchability. Poultry Science. 1994; 73(12): 1838-1845. Available from: https://academic.oup.com/ps/article-abstract/73/12/1838/1585424

12. Silva, EN. Doenças de transmissão vertical. In: MACARI, M.; GONZALES, E. Manejo da incubação. 2. ed. Jaboticabal: FACTA, 2003. Cap.4, p.379-393. Available from: http://facta.org.br/produto/manejo-deincubacao/

13. Barancelli, GV, Martin, JGP, Porto, E. Salmonella em ovos: relação entre produção e consumo seguro.

Cienc. anim. bras., Goiânia, v.20, 1-10, e-49586, 2019 
Segurança Alimentar e Nutricional. 2000; 19(2), 73-82. Available from: https://periodicos.sbu.unicamp.br/ojs/ index.php/san/article/view/8634612

14. French, N. Supplying what the embryo needs to successfully hatch. International Hatchery Practice. Emigsville, 2010; 24(7): 21-23. Available from: http:/www.positiveaction.info/emails/DIGITAL/IHP.html

15. Deeming DC. What is chick quality? World Poultry Science Journal. 2000; 11:34-35. Available from: https://www.cambridge.org/core/journals/world-s-poultry-science-journal

16. Fasenko GM, O’Dea EE. Evaluating Broiler Growth and Mortality in Chicks with Minor Navel Conditions at Hatching. Poultry Science, 2008; 87(3):594-597. Available from: https://academic.oup.com/ps/ article/87/3/594/1494737

17. Oviedo-Rondón EO. Desafios e necessidades para o manejo da incubação. In: Macari M, Gonzales E, Patricio IS, Nääs IA, Martins PC, editors. Manejo da Incubação. Jaboticabal: Facta, 2013. p. 383-396. Available from: http://facta.org.br/produto/manejo-de-incubacao/

18. Rocha JSR, Lara LJC, Baião NC, Cançado SV, Triginelli MV, Leite JFC. Efeito da classificação dos ovos sobre a uniformidade, o desempenho e o rendimento de abate de frangos de corte. Arq. Bras. Med. Vet. Zootec. [Internet]. 2008 aug 12 [cited 2017 Aug 11]; 60 (5): 1181-1187, 2008. Avaible from: http://www.scielo.br/pdf/ abmvz/v60n5/21.pdf

19. Sinclair RW, Robinson FE, Hardin RT. The effects of parent age and posthatch treatment on broiler performance. Poultry Science, 1990; 69(4): 526-534. Available from: https://academic.oup.com/ps/articleabstract/69/4/526/1514119

20. Hodgetts B. Successfully closing the hatch window. International hatchery Practice, 2006; 20 (5) 23. Available from: http://www.positiveaction.info/pdfs/articles/hp20.5p23.pdf 